\title{
Treatment of Pediatric Diabetic Ketoacidosis in Canada: A Review of Treatment Protocols from Canadian Pediatric Emergency Departments
}

\author{
Steven A Skitch, MD, PhD*; Rahim Valani, MD, MMedEd*
}

\section{ABSTRACT}

Objective: Diabetes is the most common pediatric endocrine disorder, and diabetic ketoacidosis (DKA) is the leading cause of diabetes-related morbidity and mortality. This article reviews pediatric DKA treatment protocols from across Canada and identifies similarities and differences.

Methods: Pediatric tertiary centres in Canada were asked for a copy of their DKA treatment protocol. For each protocol, we collected information on the amount of initial fluid bolus, maintenance fluid rate, insulin infusion rate, potassium replacement, monitoring and adjustment for serum glucose, administration of bicarbonate, and treatment for cerebral edema.

Results: Responses were obtained from 13 sites. Treatment guidelines were consistent in their recommendations on timing and dosage of intravenous insulin, potassium replacement, monitoring and adjusting for serum glucose, and management of cerebral edema. Variability in treatment protocols was found chiefly in volume of initial fluid bolus (range: $5-20 \mathrm{~mL} / \mathrm{kg}$ ) and length of time boluses should be administered (20-120 min), maintenance fluid rates (based on weight or a 48-hr deficit), and the role of bicarbonate administration.

Conclusions: This is the first review of treatment protocols for pediatric DKA in Canada. It identified many common approaches but noted specific differences in fluid boluses, maintenance fluid rates, and bicarbonate administration. The extent of variation indicates the need for further study, as well as national guidelines that are evidence-based and consistent with best practices.

\section{RÉSUMÉ}

Objectifs: Le diabète est l'affection endocrinienne la plus fréquente chez les enfants, et l'acidocétose diabétique (ACD) est la principale cause de morbidité et de mortalité liées au diabète. Les auteurs passent en revue, dans l'article, les protocoles de traitement de l'ACD chez les enfants, appliqués partout au Canada, puis ils relèvent les ressemblances et les différences qui existent entre eux.

\begin{abstract}
Méthode: Les auteurs ont demandé aux centres de soins tertiaires en pédiatrie, au Canada, de leur faire parvenir une copie de leur protocole de traitement de I'ACD. Il y a eu, pour chacun d'eux, une collecte de données sur le volume initial de liquides administrés en bolus, la vitesse d'entretien de l'administration des liquides, la vitesse de perfusion de l'insuline, la recharge potassique, la surveillance de la glycémie et l'adaptation posologique, l'administration de bicarbonate ainsi que le traitement de l'œdème cérébral.

Résultats: Treize centres ont accédé à la demande. Les recommandations sur le moment de l'administration de l'insuline intraveineuse et les doses prescrites, la recharge potassique, la surveillance de la glycémie et l'adaptation posologique ainsi que le traitement de l'œdème cérébral respectaient les lignes directrices relatives au traitement. Toutefois, des différences ont été relevées dans les protocoles de traitement surtout en ce qui concerne le volume initial de liquides administrés en bolus (plage: $5-20 \mathrm{ml} / \mathrm{kg}$ ) et la durée d'administration des bolus (20-120 min), la vitesse d'entretien de l'administration des liquides (en fonction du poids ou de la correction de la déperdition sur $48 \mathrm{~h}$ ) et le rôle de l'administration de bicarbonate. Conclusions: II s'agit du premier examen méthodique des protocoles de traitement de I'ACD chez les enfants au Canada. De nombreux points communs ont été relevés, mais il existe certaines différences en ce qui concerne l'administration de liquides en bolus, la vitesse d'entretien de l'administration des liquides et l'administration de bicarbonate. L'importance des différences fait ressortir la nécessité de mener d'autres études et d'élaborer des lignes directrices nationales, fondées sur des données probantes et conformes aux pratiques exemplaires.
\end{abstract}

Keywords: Pediatric, diabetic, diabetic ketoacidosis management

\section{INTRODUCTION}

Diabetes is the most common endocrine disorder in Canadian children, affecting an estimated 25.9 per

From the *Division of Emergency Medicine, McMaster University, Hamilton, ON.

Correspondence to: Dr. Rahim Valani, Division of Emergency Medicine, McMaster University, Hamilton General Hospital, McMaster Clinic-2nd Floor, 237 Barton Street East, Hamilton, ON, L8L 2X2; Email: valanir@mcmaster.ca

(c) Canadian Association of Emergency Physicians 2015 CJEM 2015;17(6):656-661

DOI 10.1017/cem.2015.56 
100,000 per year, which is among the world's highest incidence rates. ${ }^{1}$ Diabetic ketoacidosis (DKA) is the leading cause of diabetes-related morbidity and mortality in the pediatric population. ${ }^{2}$ Understanding the pathophysiology, treatment, and complications of DKA is essential for the emergency department (ED) physician, who is likely to encounter pediatric patients presenting with this condition.

DKA is defined biochemically by the triad of hyperglycemia (serum glucose $>11 \mathrm{mmol} / \mathrm{L}$ ), acidosis (venous $\mathrm{pH}<7.3$ or bicarbonate $<15 \mathrm{mmol} / \mathrm{L}$ ), and ketosis (presence of ketones in blood or urine). ${ }^{3}$ Management of DKA is aimed at reversing these changes by replacing fluid, correcting electrolyte imbalances, and managing hyperglycemia and acidosis through insulin administration. Treating the intercurrent illness is also necessary for the optimal management of DKA.

Cerebral edema (CE) complicates $0.5-1.0 \%$ of pediatric admissions for DKA. The mortality rate for this devastating condition is $25 \%$, and $5 \%-26 \%$ of its survivors suffer permanent neurological deficits. ${ }^{4-7}$ Large case-control studies have identified several markers of increased illness severity as significant risk factors for the development of CE among pediatric DKA patients. ${ }^{8}$ Risk factors include both patient-related and treatment-related variables. Patient-related risk factors include: younger age, newly diagnosed diabetes on DKA presentation, and greater illness severity as reflected by lower baseline serum bicarbonate, higher serum urea, and lower partial pressure of arterial carbon dioxide. Treatment-related risk factors include: administration of bicarbonate, larger fluid volumes administered during the initial four hours of treatment, and administration of insulin within the first hour of treatment. Concern about iatrogenic harm has led to the development of pediatric DKA management protocols that aim to standardize the care of these patients. These protocols advocate limiting the volume of initial fluid resuscitation, replacing fluid deficits over 48 hours with prolonged use of isotonic fluids, and the administration of low-dose continuous insulin infusions following an initial period of fluid administration as the standard of care. ${ }^{3}$

Canada lacks a clear national consensus on a treatment protocol for the emergency management of pediatric DKA. The tendency to develop protocols at the local or regional levels has the potential to contribute to practice variation among health authorities, provinces, and institutions. This is supported by a previous study comparing pediatric treatment protocols used in hospitals throughout the United Kingdom, which found significant regional practice variation. ${ }^{9}$ To date, no study has been published summarizing the approaches to pediatric DKA management adopted in Canada. This paper reviews current practice guidelines in pediatric tertiary care centres across Canada to better understand best practices in managing this serious complication.

\section{METHODS}

Research ethics approval was obtained through McMaster University (REB File No: 14-242-C). Thirteen sites across Canada were asked for the protocol used to guide the acute management of pediatric DKA. For each hospital, a representative from either the Division of Endocrinology or that of Pediatric Emergency Medicine was asked, for purposes of our study, to supply a copy of their current DKA treatment protocol. The protocols were analyzed from the following perspectives: treatment for shock, initial fluid rate, maintenance fluid rate and composition, insulin infusion rate, potassium replacement, monitoring and adjusting for serum glucose, and administration of bicarbonate. Data were abstracted from each protocol by the study lead author. Following completion of data analysis and manuscript preparation, a draft was sent to each participating institution to ensure accuracy of data abstraction.

\section{RESULTS}

Responses were obtained from all 13 sites contacted, as follows. The protocol for one institution, BC Children's Hospital, was available in a journal article; ${ }^{10}$ three centres in Ontario, McMaster Children's Hospital, The Hospital for Sick Children (SickKids), and Children's Hospital-London Health Sciences Centre, based their treatment on provincial Ministry of Health and Long-Term Care guidelines; ${ }^{11}$ and another, Royal University Hospital, treated DKA according to the provider's own experience and preference rather than a formal institutional protocol. Each of the remaining eight centres had its own protocol, provided to us by a representative.

\section{Consistencies between protocols}

Institutional protocols were authored by committees led by representatives from the Division of Pediatric 
Endocrinology, often in consultation with representatives from relevant departments, including Emergency Medicine and Critical Care. Protocols were consistent in recommending that insulin be administered via continuous intravenous (IV) infusion at a rate of 0.1 units $/ \mathrm{kg} /$ hour following an initial period of fluid resuscitation. Protocols were also consistent in recommendations on potassium supplementation. Once children are voiding and not significantly hyperkalemic (defined as a potassium level $>5.0-5.5 \mathrm{mmol} / \mathrm{L}$ ), potassium chloride $(40 \mathrm{mEq} / \mathrm{L})$ should be added to maintenance IV fluids, and electrolyte levels frequently reassessed. Each protocol recommended that serum blood glucose be assessed hourly and that dextrose be added to maintenance fluids to prevent a precipitous decline with insulin therapy (when serum levels drop below $14-17 \mathrm{mmol} / \mathrm{L})$.

\section{Variations between protocols}

Variability between treatment protocols was found regarding initial fluid resuscitation. All protocols recommended bolus fluid resuscitation for patients presenting in shock, manifested as either cardiovascular instability or hypotension. However, the volume $(5-20 \mathrm{~mL} / \mathrm{kg})$ and rate of bolus fluid resuscitation (20-120 minutes) varied between protocols. One protocol, from Janeway Children's Hospital, recommended a moderate fluid bolus $(7 \mathrm{~mL} / \mathrm{kg})$ for tachycardia without hypotension. Similarly, St-Justine Hospital's protocol recommended a moderate fluid bolus $(10 \mathrm{~mL} / \mathrm{kg})$ for severe dehydration without overt shock.

Variability between treatment protocols was also found regarding maintenance fluid rates. Five of the guidelines we reviewed recommended calculating deficits on the basis of clinical assessment of the severity of dehydration, then making up deficits evenly over 48 hours, while continuing to satisfy maintenance requirements. A second group of five guidelines recommended running fluids at a predetermined volume depending on the child's weight.

The role assigned to bicarbonate administration also varied among centres. One treatment protocol did not provide recommendations regarding bicarbonate administration. Of the remaining protocols, five treatment protocols recommended that bicarbonate never be administered to pediatric DKA patients, while the remainder recommended that its administration be considered only for patients with severe acidosis $(\mathrm{pH}<6.9)$ or severe refractory shock. Treatment protocol recommendations for intravenous fluid resuscitation and bicarbonate administration are summarized in Table 1. For comparison, treatment protocol recommendations from the International Society for Pediatric and Adolescent Diabetes, a widely cited and disseminated international treatment guideline, are appended to Table 1 .

\section{DISCUSSION}

This study reviews the treatment protocols for pediatric DKA currently followed at pediatric tertiary care centres in Canada. It found several common management practices across the country, particularly in IV fluid composition, management of electrolytes (specifically potassium), and dextrose supplementation. Discrepancies among protocols were noted in initial IV fluid boluses, maintenance fluid rates, and bicarbonate administration. Key differences were seen in rates of initial fluid resuscitation when patients presented with signs and symptoms of shock. This diversity could lead to differences in the amount and rate of fluids given to patients during initial resuscitation. Our results are consistent with those of a previous study comparing pediatric treatment protocols used in hospitals throughout the United Kingdom. ${ }^{9}$ It found substantial variation among 25 hospital treatment protocols in the rates of fluid administration recommended, as initial boluses ranged from $5-25 \mathrm{~mL} / \mathrm{kg}$ given over 10-60 minutes. Variation between protocols in recommendations regarding intravenous fluid volumes and rates is not surprising. There is longstanding controversy regarding both the role of intravenous fluids in the pathogenesis of $\mathrm{CE}$ and the optimal fluid resuscitation strategy for pediatric DKA. ${ }^{12}$ Theoretically, aggressive fluid resuscitation runs the risk of precipitating CE by causing osmotic swelling of brain cells as serum osmolality drops. Evidence for this outcome, however, has been limited to retrospective studies that have often failed to control for baseline illness severity. ${ }^{12}$ Several investigators are now questioning the association between fluid administration and CE in DKA patients based upon multiple lines of evidence. First, several case-control studies showed that many pediatric DKA patients whose course was complicated by CE showed signs of CE before the initiation of therapy. ${ }^{7}$ Second, a comparison of affected children who developed $\mathrm{CE}$, 


\begin{tabular}{|c|c|c|c|c|}
\hline Source & Bolus IVF for shock & $\begin{array}{l}\text { Initial hourly IVF rate } \\
\text { without shock }\end{array}$ & Maintenance IVF & Bicarbonate Administration \\
\hline BC Children's Hospital ${ }^{14}$ & $\begin{array}{l}\text { 5-10 ml/kg over } 1-2 \text { hours; } \\
\text { maximum } 30 \mathrm{~mL} / \mathrm{kg}\end{array}$ & $\begin{array}{l}\text { Same as calculated } \\
\text { maintenance rate }\end{array}$ & $\begin{array}{l}\text { Calculated deficit plus } \\
\text { maintenance replaced } \\
\text { over } 48 \text { hours }\end{array}$ & $\begin{array}{l}\text { Consider for } \mathrm{pH}<6.9 \text { or } \\
\text { cardiac failure }\end{array}$ \\
\hline $\begin{array}{l}\text { Alberta Children's } \\
\text { Hospital }\end{array}$ & $\begin{array}{l}10-20 \mathrm{ml} / \mathrm{kg} \text { over } 15-30 \\
\text { minutes; maximum } \\
40 \mathrm{~mL} / \mathrm{kg}\end{array}$ & $\begin{array}{l}\text { Double the calculated } \\
\text { maintenance rate }\end{array}$ & $\begin{array}{l}\text { Calculated deficit plus } \\
\text { maintenance replaced } \\
\text { over } 48 \text { hours }\end{array}$ & $\begin{array}{l}\text { Consider for symptomatic } \\
\text { hyperkalemia or poor } \\
\text { myocardial function }\end{array}$ \\
\hline $\begin{array}{l}\text { Stollery Children's } \\
\text { Hospital }\end{array}$ & $\begin{array}{l}10 \mathrm{~mL} / \mathrm{kg} \text { over } 1 \text { hour; may } \\
\text { repeat if needed, } \\
\text { maximum not specified }\end{array}$ & $10 \mathrm{~mL} / \mathrm{kg}$ over 1 hour & $\begin{array}{l}\text { Calculated deficit plus } \\
\text { maintenance replaced } \\
\text { over } 48 \text { hours }\end{array}$ & $\begin{array}{l}\text { Recommends against } \\
\text { giving bicarbonate }\end{array}$ \\
\hline $\begin{array}{l}\text { Chidren's Hospital-HSC } \\
\text { Winnipeg }\end{array}$ & $\begin{array}{l}20 \mathrm{~mL} / \mathrm{kg} \text { over } 20-30 \\
\text { minutes; maximum } \\
40 \mathrm{~mL} / \mathrm{kg}\end{array}$ & $\begin{array}{l}\text { Same as calculated } \\
\text { maintenance rate }\end{array}$ & $\begin{array}{l}\text { Calculated deficit plus } \\
\text { maintenance and } \\
\text { ongoing losses replaced } \\
\text { over } 48 \text { hours }\end{array}$ & $\begin{array}{l}\text { Recommends against } \\
\text { giving bicarbonate }\end{array}$ \\
\hline $\begin{array}{l}\text { Ontario Ministry of } \\
\text { Health }^{15 *}\end{array}$ & $\begin{array}{l}10 \mathrm{~mL} / \mathrm{kg} \text { over } 1 \text { hour; } \\
\text { may repeat if needed, } \\
\text { maximum not specified; }\end{array}$ & $7 \mathrm{~mL} / \mathrm{kg}$ over 1 hour & $3.5-5 \mathrm{~mL} / \mathrm{kg} / \mathrm{hr}$ & $\begin{array}{l}\text { Consider for life-threatening } \\
\text { hyperkalemia, ionotrope- } \\
\text { resistant shock or cardiac } \\
\text { arrest }\end{array}$ \\
\hline $\begin{array}{l}\text { Children's Hospital of } \\
\text { Eastern Ontario }\end{array}$ & $\begin{array}{l}10 \mathrm{~mL} / \mathrm{kg} \text { over } 20-30 \\
\text { minutes; may repeat if } \\
\text { needed, maximum not } \\
\text { specified }\end{array}$ & $\begin{array}{l}\text { Same as calculated } \\
\text { maintenance rate }\end{array}$ & $\begin{array}{l}\text { Based on patient weight; } \\
\text { 3-9 kg: } 6 \mathrm{~mL} / \mathrm{kg} / \mathrm{hr} \\
\text { 10-19 kg: } 5 \mathrm{~mL} / \mathrm{kg} / \mathrm{hr} \\
\text { >19 kg: } 4 \mathrm{~mL} / \mathrm{kg} / \mathrm{hr} \\
\text { (max } 250 \mathrm{~mL} / \mathrm{hr} \text { ) }\end{array}$ & Consider for $\mathrm{pH}<6.9$ \\
\hline Hôpital Sainte-Justine & $20 \mathrm{~mL} / \mathrm{kg}$ over 20 minutes & $\begin{array}{l}10 \mathrm{~mL} / \mathrm{kg} \text { over } 1 \text { hour for } \\
\text { severe dehydration } \\
\text { without shock; otherwise } \\
5 \mathrm{~mL} / \mathrm{kg} \text { over } 1 \text { hour }\end{array}$ & $\begin{array}{l}5 \mathrm{~mL} / \mathrm{kg} / \mathrm{hr}(\max \\
250 \mathrm{~mL} / \mathrm{hr})\end{array}$ & $\begin{array}{l}\text { Recommends against } \\
\text { giving bicarbonate }\end{array}$ \\
\hline \multirow[t]{2}{*}{$\begin{array}{l}\text { Montreal Children's } \\
\text { Hospital }\end{array}$} & $\begin{array}{l}10 \mathrm{~mL} / \mathrm{kg} \text { over } 30 \text { minutes; } \\
\text { may repeat if needed, } \\
\text { maximum not specified }\end{array}$ & $7 \mathrm{~mL} / \mathrm{kg}$ over 1 hour & & \\
\hline & $\begin{array}{l}\text { Based on patient weight; } \\
\text { 3-9 kg: } 6 \mathrm{~mL} / \mathrm{kg} / \mathrm{hr} \\
\text { 10-19 kg: } 5 \mathrm{~mL} / \mathrm{kg} / \mathrm{hr} \\
\text { >19 kg: } 4 \mathrm{~mL} / \mathrm{kg} / \mathrm{hr} \\
\text { (max } 250 \mathrm{~mL} / \mathrm{hr} \text { ) }\end{array}$ & Not mentioned & & \\
\hline IWK Health Centre & $\begin{array}{l}10 \text { mL/kg over } 30-60 \\
\text { minutes; maximum not } \\
\text { specified }\end{array}$ & $\begin{array}{l}\text { Same as calculated } \\
\text { maintenance rate }\end{array}$ & $\begin{array}{l}\text { Based on patient weight; } \\
\text { 3-9 kg: } 6 \mathrm{~mL} / \mathrm{kg} / \mathrm{hr} \\
\text { 10-19 kg: } 5 \mathrm{~mL} / \mathrm{kg} / \mathrm{hr} \\
\text { >19 kg: } 4 \mathrm{~mL} / \mathrm{kg} / \mathrm{hr} \\
\text { (max } 250 \mathrm{~mL} / \mathrm{hr} \text { ) }\end{array}$ & Consider for $\mathrm{pH}<6.9$ \\
\hline $\begin{array}{l}\text { Janeway Children's } \\
\text { Hopsital }\end{array}$ & $\begin{array}{l}10-20 \mathrm{~mL} / \mathrm{kg} \text { over } 30-60 \\
\text { minutes; maximum } \\
40 \mathrm{~mL} / \mathrm{kg}\end{array}$ & $\begin{array}{l}7 \mathrm{~mL} / \mathrm{kg} \text { over } 30-60 \\
\text { minutes for tachycardia; } \\
\text { otherwise same as } \\
\text { calculated maintenance } \\
\text { rate }\end{array}$ & $\begin{array}{l}\text { Calculated deficit plus } \\
\text { maintenance replaced } \\
\text { over } 48 \text { hours }\end{array}$ & $\begin{array}{l}\text { Recommends against } \\
\text { giving bicarbonate }\end{array}$ \\
\hline $\begin{array}{l}\text { International Society } \\
\text { for Pediatric and } \\
\text { Adolescent Diabetes } \\
(2009)^{3}\end{array}$ & $\begin{array}{l}10 \mathrm{ml} / \mathrm{kg} \text { over } 1-2 \text { hours; } \\
\text { May repeat if need, } \\
\text { maximum } 30 \mathrm{~mL} / \mathrm{kg}\end{array}$ & $\begin{array}{l}\text { Same as calculated } \\
\text { maintenance rate }\end{array}$ & $\begin{array}{l}\text { Calculated deficit plus } \\
\text { maintenance replaced } \\
\text { over } 48 \text { hours }\end{array}$ & $\begin{array}{r}\text { Consider for } \mathrm{pH}<6.9 \text { or life } \\
\text { threatening hyperkalemia }\end{array}$ \\
\hline
\end{tabular}


with those treated for DKA who did not, found no significant association between rate of fluid administration and occurrence of $\mathrm{CE}$, after controlling for initial illness severity. ${ }^{4,7}$ Third, the widespread establishment of more conservative fluid replacement guidelines has not been associated with a concomitant fall in the rates of CE. ${ }^{13}$ Fourth, imaging studies have found that pediatric patients with DKA show evidence of subclinical CE on MRI before therapy has begun. ${ }^{14,15}$ Fifth, in a randomized trial of pediatric DKA patients, more aggressive fluid administration did not increase the occurrence of subclinical CE as measured by MRI. ${ }^{16}$ The optimal fluid resuscitation strategy for the treatment of DKA is currently being studied through an ongoing randomized controlled trial. ${ }^{17}$

The method of calculating maintenance fluid rates for pediatric DKA patients varies from one Canadian treatment protocol to another. One group of guidelines recommends administering maintenance fluids based upon clinical assessment of volume depletion, whereas a second group recommends running fluids at a predetermined volume depending on the child's weight. This divergence in approach may be partly attributable to the difficulty of estimating a patient's degree of dehydration. Studies indicate that clinical assessment of the extent of dehydration in DKA patients is often inaccurate, owing to a tendency to overestimate dehydration because these patients appear more dehydrated on clinical exam than they actually are. ${ }^{18}$ This may explain why some centres prefer a strictly weight-based approach rather than a clinical assessment of dehydration.

Canadian protocols vary in their recommendations on bicarbonate administration during treatment for DKA. Of those protocols discussing bicarbonate administration, five recommended against its administration, while the remaining protocols recommended it be considered only for severe refractory acidosis associated with shock. The currently available evidence indicates that bicarbonate does not improve outcomes in pediatric DKA, and may even be associated with harm. Although no randomized controlled trials have been conducted, one case-control series indicated that in pediatric DKA, bicarbonate administration neither improves clinical outcomes nor speeds metabolic recovery. ${ }^{19}$ In another case-control study, treatment with bicarbonate was associated with increased risk for the development of CE, even after controlling for initial illness severity. ${ }^{4}$ Bicarbonate administration may cause harm by decreasing delivery of tissue oxygen and, paradoxically, causing cerebrospinal fluid acidosis during treatment for DKA. ${ }^{20}$ Further research is needed to clarify the role bicarbonate administration plays in severe pediatric DKA to guide future treatment protocols.

\section{LIMITATIONS}

The current study is limited in that we only examined treatment protocols rather than actual treatment practices. Furthermore, we only obtained treatment protocols from pediatric tertiary care centers. Research to date suggests that actual practice is likely to vary widely, depending on provider experience and on locale. Rutledge and Couch $^{21}$ conducted a five-year retrospective review of all DKA admissions to a Canadian pediatric tertiary care centre. They reported that most patients were initially managed in a nonpediatric $\mathrm{ED}$, where they were given almost double the amount of initial resuscitation fluids received by patients managed in a pediatric ED. The authors concluded that fluid management in the former is often excessive and inconsistent with current guidelines. It is noteworthy that the risk of DKA-related complications such as CE did not increase when patients were seen first in non-pediatric EDs. Future research is needed to assess provider knowledge and adherence to pediatric DKA treatment protocols and their impact on clinical practice and patient outcome.

Emergency physicians need to understand the pathophysiology of pediatric DKA, and the best evidence to manage this life-threatening condition. They should be aware of treatment guidelines followed in their locality and cognizant of the differences in opinion regarding management of this condition. Although differing on several important issues, current management protocols do provide a guide in the management of these patients. The extent of variation between different protocols indicates the need for further study and collaboration to develop national guidelines that are evidence-based and consistent with best practices.

Acknowledgements: The authors would like to thank the representatives of the Divisions of Pediatric Endocrinology and Pediatric Emergency Medicine from the pediatric tertiary care centres throughout Canada who generously provided us with copies of their local pediatric diabetic ketoacidosis protocols and permitted us to use them for purposes of this review.

Competing interests: None declared. 


\section{REFERENCES}

1. International Diabetes Federation. IDF Diabetes Atlas, 6th edition; 2013. Available at: http://www.idf.org/diabetesatlas (accessed November 2013).

2. Patterson CC, Dahlquist G, Harjutsalo V, et al. Early mortality in EURODIAB population-based cohorts of type 1 diabetes diagnosed in childhood since 1989. Diabetologia 2007;50(12):2439-42.

3. Wolsdorf J, Craig ME, Daneman D, et al. Diabetic ketoacidosis in children and adolescents with diabetes. Pediatr Diabetes 2009;10(S12):118-33.

4. Glaser N, Barnett P, McCaslin I, et al. Risk factors for cerebral edema in children with diabetic ketoacidosis. New Eng 7 Med 2001;344(4):264-9.

5. Edge JA, Jakes RW, Roy Y, et al. The UK case-control study of cerebral oedema complicating diabetic ketoacidosis in children. Diabetologia 2006;49(9):2002-9.

6. Edge JA, Hawkins MM, Winter DL, et al. The risk and outcome of cerebral oedema developing during diabetic ketoacidosis. Arch Dis Child 2001;85(1):16-22.

7. Lawrence SE, Cummings EA, Gaboury I, et al. Populationbased study of incidence and risk factors for cerebral edema in pediatric diabetic ketoacidosis. 7 Pediatr 2005;146(5): 688-92.

8. Watts W, Edge JA. How can cerebral edema during treatment of diabetic ketoacidosis be avoided? Pediatr Diabetes 2014;15(4):271-6.

9. Edge JA, Dunger DB. Variations in the management of diabetic ketoacidosis in children. Diabet Med 1994;11(10): 984-6.

10. Metzger DL. Diabetic ketoacidosis in children and adolescents: an update and revised treatment protocol. BCMF 2010;52(1):24-31.

11. Ontario Ministry of Health and Long-Term Care. Emergency room management guidelines for the child with type 1 diabetes. Available at: http://www.health.gov.on.ca/ english/providers/pub/diabetes/child_poster.pdf (accessed December 2013).

12. Wolsdorf JI. The international society of pediatric and adolescent diabetes guideline for the management of diabetic ketoacidosis: do the guidelines need to be modified? Pediatr Diabetes 2014;15:277-86.

13. Hom J, Sinert R. Is fluid therapy associated with cerebral edema in children with diabetic ketoacidosis? Ann Emerg Med 2008;52(1):69-75.

14. Figueoroa RE, Hoffman WH, Momin Z, et al. Study of subclinical cerebral edema in diabetic ketoacidosis by magnetic resonance imaging T2 relaxometry and apparent diffusion coefficient maps. Endocr Res 2005;31(4):345-55.

15. Glaser NS, Wooton-Gorges SL, Marcin J, et al. Mechanism of cerebral edema in children with diabetic ketoacidosis. 7 Pediatr 2004;145(2):164-71.

16. Glaser NS, Wooton-Gorges SL, Buonocore MH, et al. Subclinical cerebral edema in children with diabetic ketoacidosis randomized to 2 different rehydration protocols. Pediatrics 2013;131(1):e73-80.

17. Glaser NS, Ghetti S, Casper TC, et al. Pediatric diabetic ketoacidosis, fluid therapy, and cerebral injury: the design of a factorial randomized controlled trial. Pediatr Diabetes 2013;14(6):435-46.

18. Ugale J, Mata A, Meert KL, et al. Measured degree of dehydration in children and adolescents with type 1 diabetic ketoacidosis. Pediatr Crit Care Med 2012;13(2):e103-7.

19. Green SM, Rothrock SG, Ho JD, et al. Failure of adjunctive bicarbonate to improve outcome in severe pediatric diabetic ketoacidosis. Ann Emerg Med 1998;31(1):41-8.

20. Chua HR, Schneider A, Bellomo R. Bicarbonate in diabetic ketoacidosis-a systematic review. Ann Intensive Care 2011; $1(1): 23$.

21. Rutledge J, Couch R. Initial fluid management of diabetic ketoacidosis in children. Am $\mathcal{F}$ Emerg Med 2000;18(6):658-60. 